\title{
Public Participation in Environmental Decision Making in India: a Critique
}

\author{
Dr. Madhuri Parikh \\ (Institute of Law, Nirma University, India)
}

\begin{abstract}
The modern technological state aims at reconciling the conflict between the environmental values and the development goals by adopting the sustainable approach for economic development. Environment Impact Assessment process is an instrument in reconciling this conflict by implementing the concept of sustainable development as it ensures public participation in environmental decision making in India. It is a legal strategy which evaluates the potential beneficial and adverse impacts of development projects on the environment, taking into account environmental, social, cultural and aesthetic considerations. It determines the viability of a project. The present paper critically analyses the role and scope of the participation of people in environmental decision making in India with special reference to Environment Impact Assessment process in India.
\end{abstract}

Keywords - Development, Environment Protection, Environment Impact assessment, public participation, sustainable development.

\section{INTRODUCTION}

An effective enforcement of the right to participation, right to information and right to access to justice secures protection of human rights. The right to participation allows people to be part of the decision making process through consultation and comments, and to have their opinion heard. Public participation can be described as ${ }^{1}$ the real involvement of all social actors in social and political decision-making processes that potentially affect the communities in which they live and work. It is an interaction between government and civil society, including the process by which government and civil society open dialogue, establish partnerships, share information, and otherwise interact to design, implement, and evaluate development policies, projects and programs. It is regarded also as a spin-off to decentralization as a contemporary trend in local governance. ${ }^{2}$ Commonly used participatory tools include public hearings, notice and consultation, citizen ombudsmen and judicial review mechanisms ${ }^{3}$.

\section{IMPORTANCE OF PUBLIC PARTICIPATION IN DECISION} MAKING PROCESS

The rationale and importance of public participation in the environmental decision making can be explained in the following words:With increased protection of environment....States have assumed the responsibility to meet dangers and risks, which may threaten a great number of citizens and even the general public. The open landscape, the water and the air, have come to be considered as the common property of all, and their rational management is not only in the interest of one single individual but in the interest of all. Therefore, States have increasingly begun to recognize that, in the law of environment protection, the traditional structures of the individual participation and judicial protection of individual are inadequate, and the public, interested citizens and organizations ought to have the opportunity to participate in the administrative decision making process... When it is the public who are expected to accept and comply with those measures, the public should have the chance to develop and articulate its opinion, and to air it during the environmental decision making process. ${ }^{4}$

\footnotetext{
${ }^{1}$ R. Picolotti and D.Taillant (Ed.), Linking Human Rights and the Environment, (Tucson, AR: University of Arizona Press,2003) 50.

${ }^{2}$ UN Habitat Report, State of the Worlds' Cities, 2006/2007,168.

${ }^{3}$ E. Dannemaier, Democracy in Development: Toward a Legal Framework for the Americas, Tulane Environmental Law Journal, 11, 1997, 13-14.

${ }^{4}$ Lothar Gunding, Public Participation in Environmental Decision Making, in Michael Bothe (Ed.), Trend in Environmental Policy and Law, (1980) 131, as quoted in P. Leelakrishnan, Environmental Law in India ( $3^{\text {rd }}$ Ed., Lexis Nexis Butterworths Wadwa Nagpur, 2008) 352 .
} 
In a democratic country like India, the mechanism of public participation in decision making manifests the direct democracy of people. The Public participation bridges the gap between the heterogeneous groups of the society. It tries to maintain balance between the right to environment and right to development. At one end project proponents makes efforts to succeed in convincing the acceptance of the project. They are having vast resources at their disposal. On the other hand, the public hearing in the environmental decision making plays vital role in providing true information about the impact of the big projects. When members of the public express their views on a proposed project, alternative views, otherwise not represented, are presented. This paves the way for the decision-making agency to be thorough in their analysis and thus brings quality and objectivity in the decisions. The effective public participation eliminates judicial review of the administrative action. It generates public confidence in the decision making process and ensures acceptance of the decision. The right to participation should be supported by a right to information that is accurate, accessible, timely and comprehensive $e^{5}$. It includes right to seek information from public authorities, with a corresponding duty of public authorities to collect and disseminate information ${ }^{6}$. This right enables the citizens to participate effectively in the decision making process.

Right to information and participation will have little meaning if the public lacks access to justice. The right of access to justice allows people to enforce environmental laws and remedy in case of any breach-it thus establishes a right to clean environment ${ }^{7}$.Access to justice allows affected communities and environmental activists to challenge decision adopted by public authorities or businesses that have failed to comply with environmental laws ${ }^{8}$. The sources of the above mentioned procedural rights are international, regional and national laws. At the international level, several interrelated factors have influenced the growth of participatory processes in decision-making ${ }^{9}$. The growth of the procedural rights at international level and the factors responsible for that have been discussed in detail in the part three of the paper.

\section{EFFORTS AT INTERNATIONAL LEVEL TO SECURE A RIGHT TO PARTICIPATION IN ENVIRONMENTAL DECISION MAKING}

At the international level, the development of procedural environmental rights can be divided into two stages of development: pre-and-post 1992. As earlier as 1948, the Universal declaration on Human rights provided generalized rights of access to information ${ }^{10}$ and justice ${ }^{11}$.Article 21 of Universal Declaration of Human Rights (1948) provides:

(1) Everyone has the right to take part in the government of his country, directly or through freely chosen representatives.

(2) Everyone has the right of equal access to public service in his country.

(3) The will of the people shall be the basis of the authority of government; this will, shall be expressed in periodic and genuine elections which shall be by universal and equal suffrage and shall be held by secret vote or by equivalent free voting procedure. ${ }^{12}$

The above mentioned participatory rights, as set out in UDHR ${ }^{13}$ are more precisely limited to suffrage and the right to run public office. They are guaranteed in relation to participation in the government. These rights are narrower than a right to take part in the conduct of public affairs, as enshrined in the International Covenant on Civil and Political Rights (1966) ${ }^{14}$. Article 25 of ICCPR provides that:

5 N. Popovic, The Right to Participate in Decisions that Affect the Environment, Pace Environmental Law Review, 10 (2), 1993, 683-709.

6 S.Stec andS.Casey-Leftkowitz, The Aarhus Convention: An Implementation Guide, UNECE: Geneva,2000, 29.

T. Hunte and K. Lunde, Access to Justice and Environmental Protection: International and Domestic Perspectives, Journal of Environment and Development ,7, 1998, 437-41.

${ }^{8}$ Ibid.

9 B.Reichardson and J.Razzaque, Public Participation in the Environmental Decision-making, in B.J. Richardson and S. Wood (Ed.), Environmental law for Sustainability Critical Reader, (Oxford: Hart Publishing,2006) 165-94.

${ }^{10}$ Article 19 of Universal Declaration of Human Rights, G.A. res. 217A (11), U.N. Doc. A/810, 10th December 1948, 71 [hereinafter referred as UDHR].

${ }^{11}$ Ibid. Article 8 and 10, UDHR.

${ }^{12}$ Universal Declaration of Human Rights, G.A. res. 217A (11), U.N. Doc. A/810, 10th December 1948,71 [hereinafter referred as UDHR].

${ }^{13}$ Ibid.

${ }^{14}$ International Covenant on Civil and Political Rights, G.A. Res. 2200A (XXI), 21 U.N. GAOR Supp.(No. 16), 52, U.N. Doc. A/6316 (1966), 999 U.N.T.S. 171, 16 December 1966 (entered into force: 23 March 1976) [hereinafter referred as ICCPR]. 
Every citizen shall have the right and the opportunity, without any of the distinctions[such as race, colour, sex, language, religion, political or other opinion, national or social origin, property, birth or other status] and without unreasonable restrictions:

(a) To take part in the conduct of public affairs, directly or through freely chosen representatives;

(b) To vote and to be elected at genuine periodic elections which shall be by universal and equal suffrage and shall be held by secret ballot, guaranteeing the free expression of the will of the electors;

(c) To have access, on general terms of equality, to public services in his country.

Article 19(2) of ICCPR ${ }^{15}$ guarantees citizens the freedom to seek, receive and impart information and ideas of all kinds. The above mentioned rights emphasized universal suffrage in relation to (representative) public affairs bodies. It does not provide remedy for the adverse effects of privatization. It is the process of privatization that affects what constitutes public affairs. This narrow scope of public participation will not bring desired result in environment related issues since the private sector is also one of the important key players in this field. In most countries law and policy for ensuring the protection of human health and the environment rely heavily on governmental administrations.

The period between the 1972 Stockholm conference and Rio declaration in 1992 has been a growing recognition of procedural tools to protect the environment. The 1972 Stockholm Conference indirectly refers to public participation by talking about equitable sharing of common efforts of citizens, communities, government and private sectors in order to defend and improve the human environment ${ }^{16}$.In 1982, the World Charter for nature has stipulated that "All persons in accordance with their national legislation shall have the opportunity to participate, individually or with others, in the formulation of decisions of direct concern to their environment, and shall have access to means of redress when their environment has suffered damage or degradation". ${ }^{17}$ It also states "All planning shall include, among its essential elements, the formulation of strategies for the conservation of nature, the establishment of inventories of ecosystems and assessments of the effects on nature of proposed policies and activities, all these elements shall be disclosed to the public by appropriate means in time to permit effective consultation and participation." The same principle was restated in Tokyo Declaration of World Commission on Environment and Development ${ }^{19}$, "Greater public participation and free access to relevant information should be promoted in decision making process touching on environment and development issues." The 1991 Hague Recommendation on International Environmental Law also emphasized the same point. $^{20}$

Affirming the public participation in the 1992 Rio Declaration on Environment and Development, it is clearly laid down "Environment issues are best handled with the participation of all concerned citizens, at the relevant level. At the national level, each individual shall have the appropriate access to information concerning the environment that is held by public authorities including information on hazardous materials and activities in their communities and the opportunity to participate in decision making processes. States shall facilitate and encourage public awareness and participation by making information widely available. Effective access to judicial and administrative proceedings, including redress and remedy shall be provided. ${ }^{21}$ Article 14 states, "Impact Assessment and Minimizing Adverse Impacts, each contracting party, as far as possible and as appropriate shall: a) introduce appropriate procedures requiring environmental impact assessment of its proposed projects, that are likely to have significant adverse effects on biological diversity with a view to avoiding or minimizing such effects and where appropriate, allow for public participation in such procedures. The UN Framework Convention on Climate Change, in Article $4{ }^{22}$ reiterated " all parties ...shall (I) promote and cooperate in education, training and public awareness related to climate change and encourage the widest participation in this process, including that of nongovernmental organization. Likewise, the 1991 Convention on

\footnotetext{
${ }^{15}$ Supra note, 14.

${ }^{16}$ Preamble; Stockholm Declaration of the United Nations Conference on the Human Environment ,1972, UN Doc. A/Conf. 48/14, reprinted in ILM 11, 1416.

${ }^{17}$ Principle 23, World Charter for Nature, 1982, ILM 22, 455
}

${ }^{18}$ Principle 16. Ibid.

19 Principle 5, Tokyo Declaration, dated 27 February 1987. The full text of the Declaration is published in Our Common Future (Oxford : Oxford University Press, 1987)

${ }^{20}$ Principle I.3d, IV.7 a-c -"in developing environmental policies at the national and international levels, states should apply inter-alia: the right of access for the public to and the duty of the states to provide information relating to environmental impacts and risks and related health hazards" .Equal and full access to information, for individuals and institutions, must be recognized as a prerequisite to implementing certain fundamental rights.

${ }^{21}$ Principle 10, Rio Declaration on Environment and Development (1992) ILM 31, 874.

${ }^{22}$ Reprinted in (1992) 3 ILM ,848 entered into force on $21^{\text {st }}$ March 1994. 
Environmental Impact Assessment in Trans boundary Context (the Espoo Convention) ${ }^{23}$ and entered into force in September 1997)Article 3 states:" the concerned parties shall ensure that the public of the affected party in the areas likely to be informed of , and be provided with possibilities for making comments or objections to the competent authority of the party of origin, either directly to this authority or, where appropriate, through the party of origin, the 1992 convention on the Trans boundary Effects of Industrial Accidents etc states as follows:

1. The parties shall ensure that adequate information is given to the public in areas capable of being affected by an industrial accident arising out of hazardous activity.

2. The Party of origin shall give the public in the areas of capable of being affected opportunity to participate in relevant procedures with the aim of making known its views and concerns on prevention and preparedness measures." 24

The 1980s movement to make a connection between human rights and the environment underscored the need for more concrete commitments and culminated on the 1994 Draft declaration of principles on Human rights and Environment ${ }^{25}$. This declaration sets a framework on the international environmental human rights law. While the 1972 Stockholm and Rio Declarations have played a crucial role in the development of participatory tools at national level. After Stockholm and Rio Declarations, most international environmental instruments imposed positive obligations on states to take measures to improve information on environmental matters $^{26}$. It has great positive influence at international level. The procedural rules of some international courts and tribunals allow people to participate in court proceedings. Direct participation is allowed, for example, in the World Bank Inspection Panel, where private citizens, including NGOs, who believe that their interests have been or could be directly harmed by a project financed by the World Bank, can bring an action ${ }^{27}$.

The 1998 UNECE Aarhus Convention brought about a unique development in procedural rights to protect the environment. The Convention adopts rights bases approach to information, participation and justice, makes reference to a substantive right to a healthy environment and allows people to enforce their procedural and substantive environmental rights in court. The procedural rights conferred on the public are to be applied without discrimination as to citizenship, nationality or domicile ${ }^{28}$.According to Aarhus Convention public participation can be ensured with early notice of decision making process when all options are open to people to provide comments or input into the process ${ }^{29}$. Parties need to ensure that public authorities will make information available to the public when requested and the Convention lays down time-frames for responding to these requests ${ }^{30}$. The Arhus convention is not limited to European Union only but it has influenced many developments at international level ${ }^{31}$.In many developing countries, laws and policies are influenced by Principle 10 of the Rio declaration and international trend favoring participation of people in environmental decision making. The international movement for human rights gets reflected at national levels also. Part four of the present paper discusses the situation of procedural rights at national level particularly with reference to India.

\section{PROVISIONS OF ENVIRONMENT IMPACT ASSESSMENT AND PUBLIC PARTICIPATION IN INDIA}

\footnotetext{
${ }^{23}$ Espoo Convention on the Environment Impact Assessment of Tran-boundary context (Espoo Convention) ILM 30,1991,800.

${ }^{24}$ Ibid.

${ }^{25}$ Pring , and S.Y.Noe, The Emerging International Law of Public Participation Affecting Global Mining,

Energy and Resource Development(2002), in D. Zillman et al., Human Rights in Natural Resource

Development: Public Participation in the Sustainable Development of Mining and Energy Resources (Oxford: OUP) 11-76.

${ }^{26}$ For example, Montreal Protocol on Substances that deplete the Ozone Layer, 1987: Article 9; Climate Change Convention 1992: Article 4(1) (i) and 6; Biodiversity Convention; Article 13.

${ }^{27}$ D.Hunter, Using the World Bank Inspection Panel to defend the interests of Project-affected people, Chicago Journal of International Law 4, 2003, 201-11.

${ }^{28}$ Article 3(9) UNECE Convention on Access to Information, Public Participation decision Making and Access to justice in Environmental Matters (Aarhus Convention),1998, ILM 38, 517.

${ }^{29}$ Article 6.Ibid.

${ }^{30}$ Articles 4, 5.Ibid.

${ }^{31}$ Example, the influence of Aarhus convention on 1999 London Protocol on Water and health , 2003 UNECE Protocol on Strategic Environmental Assessment (SEA Protocol), 2000 Bio safety Protocol, 1992 Convention on Biological Diversity.
} 
In India, EIA was legally notified under the Environmental Protection Act 1986, in the year 1994. However, it was only in 1997 that the EIA Notification 1994 was amended and for the first time public involvement in the environmental clearance through the public hearing mechanism was made statutory. It specifically provided that the findings of the impact assessing authority should be based, inter alia, on the details of public inquiry. The project proponent has to submit 20 sets of documents to the state pollution control board. The board has to give notice of hearing in two newspapers of wide circulation in the locality, one which should be in the vernacular language. The notice should mention the date, time and place of public hearing. Suggestions, views, comments and objections of the public are invited within 30 days from the date of the publication of the notice. The major amendment in the notification was made in year 2006 wherein the projects have been divided into category A and B. Category B is further divided into B1 and B2. MOEF is empowered to give Environmental Clearance in Category A projects whereas Category B projects are given clearance by the state level authority State Environmental Impact Assessment Authority [SEIAA]. The process of EIA can be mentioned as below:

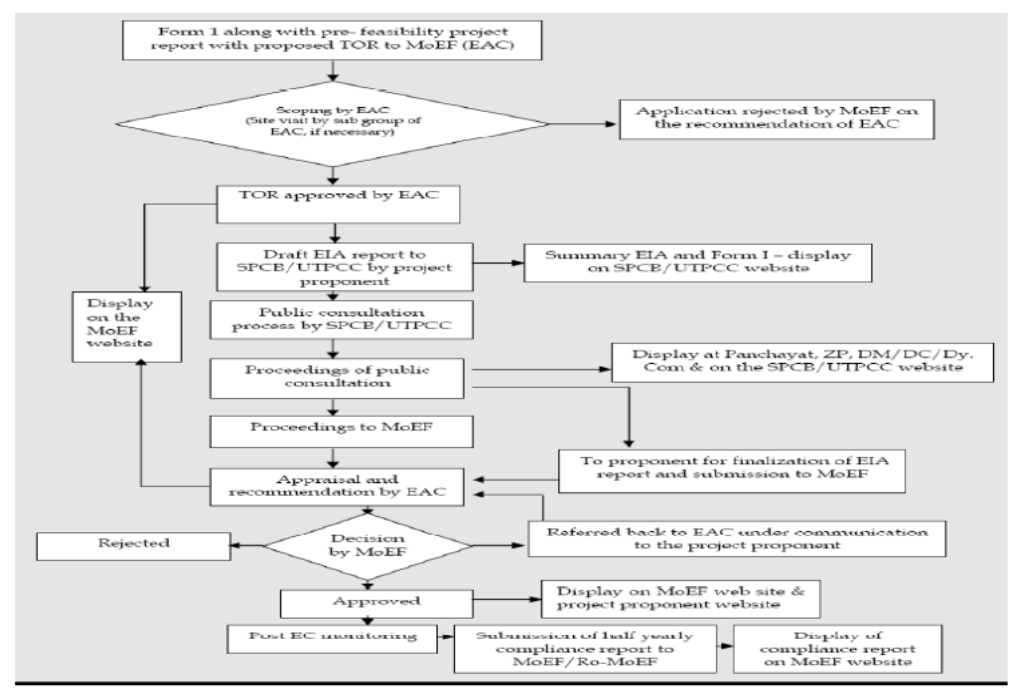

4.1 EIA process for A category projects Source: $\underline{\text { http://cseindia.org/docs/visited on 14/6/2017 }}$

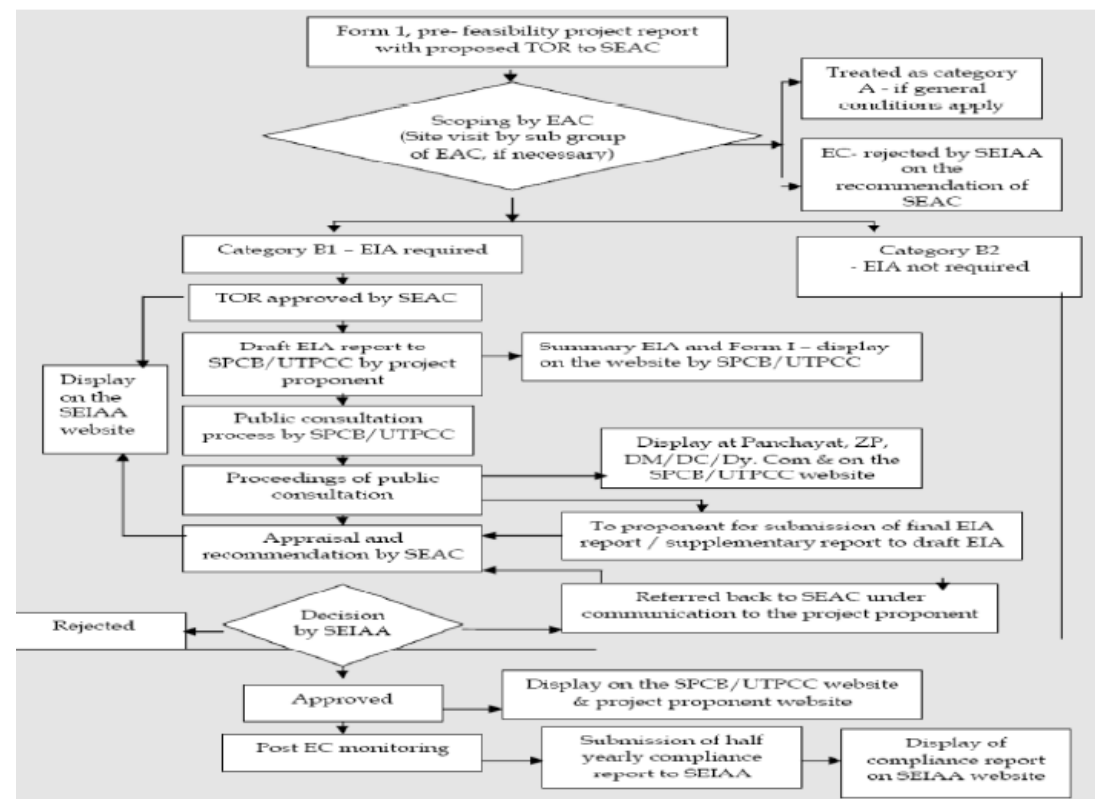

4.2 EIA process for B category projects

Source: http://cseindia.org/docs/visited on 14/6/2017

The entire EIA process involves four stages: Screening, scoping, public consultation and appraisal. The above provisions help in bridging the gap of understanding between the project sponsors and the members of the 
general public and bring public confidence into the process of decision making. It helps in ensuring public acceptance of development decisions. The provisions are available in the National Environmental Appellate Act, $1997^{32}$ to challenge the project clearance done.

\section{The Role of Indian Judiciary}

On various occasion the Supreme Court and the High Courts of India has insisted on mandatory implementation of the EIA and directly or indirectly promoted the public participation in environmental decision making. In Vedire Vankatta Reddy v. Union of India ${ }^{33}$ it has been made clear that as environmental clearance is mandatory procedure under notification 24-4-1994 must be meticulously followed. Only on such clearance by the Impact Assessment Agency of the Central Government, the project of construction of dam by the State Government of Andhra Pradesh to proceed ahead with the implementation of dam construction project till such clearance is obtained.In Narmada Bachao Andolan v. Union of India ${ }^{34}$ the environmental clearance was given by the Central Government in 1987, much prior to above notification of 1994. Even the dispute regarding the raising the height of the dam was also settled by an award given in 1978. Thereafter, the construction was taken up in 1987. The writ was filed to challenge the construction of and raising the height of dam in 1994. The Supreme Court held that when projects are undertaken and hundreds and crores of public money are spent, individual and the organization, petition in the garb of public interest litigation cannot be entertained. As the project commenced long back, it does not require environment impact assessment as required by the above notification.

In M.C.Mehta v. Union of India ${ }^{35}$,the Court made it clear that though the notification dated 29-1-1994 is not applicable to minor mineral but having regard to degradation of environment and risk involved to human health and ecology, the EIA is must. Moreover, the notification is also applicable when renewal of mining in Delhi and Haryana region of Aravalli hills causing environmental degradation was challenged. The Supreme Court appointed 'monitoring Committee' to examine the issue with certain directions.In different PIL cases, the directions of the Supreme Court went to the extent of spreading environmental awareness and literacy as well as the launching of environmental education not only at school level, but also at the college level. In M.C.Mehta v. Union of India ${ }^{36}$ the Supreme Court stressed the need for introducing such scheme, "In order for the human conduct to be in accordance with the prescription of law it is necessary that there should be appropriate awareness about what the law requires. This should be possible only when steps are taken in the adequate measures to make people aware of the indispensable necessity of their conduct being oriented in accordance with the requirements of law. ${ }^{37} \mathrm{We}$ can see the result of such approach of the Supreme Court e.g. The Bar council of India has introduced Environmental Law as a compulsory paper for legal education at the graduate level.The decision and the directions of the High Court of Gujarat in Center for Social Justice v. Union of India $^{38}$ have a persuasive impact on the development of concept of public participation in India. In this case, the court has issued following directions related to public participation in environmental decision making:

1. The place of public hearing shall be as near as possible to the proposed site and both far away from the headquarters of the taluka where the site is proposed.

2. Notice of public hearing shall be published in newspapers not less than two, which have wide circulation in region. Local government in area should also be asked to give publicity to the notice. The minimum period of notice shall be 30 days.

3. Executive summary of the project should be made available at all local places at least 30 days prior to the date of public hearing. Summary of the EIA report in the local language also shall be made available to the concerned person on demand.

\footnotetext{
${ }^{32}$ Presently, under National Green Tribunal Act, 2010.

${ }^{33}$ AIR 2005 AP 155.

${ }^{34}$ (2000) 10 SCC 664.

35 (2004) 12 SCC 18: AIR 2004 SC 4016.

${ }^{36}$ AIR 1992 SC 362.

${ }^{37}$ Ibid at pg. 384.

${ }^{38}$ AIR 2001 Guj 71.
} 
4. Quorum of the hearing panel shall be one half of the total membership. Representatives from the board and state environment department, one senior citizen and an environmentalist nominated by the collector are necessarily to be present.

5. The committee can decide such numbers of hearings as are found necessary by looking at the impact of the project on the environment. There is no hard and fast rule in this respect

6. The state pollution control board on demand shall furnish minutes of the hearing as expediously as possible. The state government or the Central government shall cause publication of the gist of clearance certificate in newspapers in which the notice for public hearing is published

7. There is no harm if the board makes reasonable levy on supplying copies of records-executive summary of the project, summary of the environment assessment.

The EIA notification 2006 has accepted many principles laid down in the above judgment, but it has not incorporated the guidelines given for the quorum of attendance in public inquiry. The expansion of the rule of locus standi has encouraged people to fight for the causes of the environment. The numerous cases filed by Mr. M.C.Mehta and various NGOs shows the positive result of the development of the participation of people in enforcing the right to environment. The successful implementation of principles of sustainable development in India is the result of the citizen's right to enforce fundamental right to clean environment.

\section{CONCLUSION AND SUGGESTIONS}

The EIA notification has been passed with a noble objective. It really implements the precautionary principle and the principle of sustainable development but there is always a question related to implementation of the same in India. The original noitifiacain has been amended number of times and many significant projects have been excluded from the mandatory public hearing process. The amendment in the notification in 2006 has diluted the purpose of the public hearing process. The 2006 amendment had restricted the involvement of the NGO in the public hearing process by restricting the scope of public hearing only for the directly affected people by the project. The rest can submit their observations and objections through written note. It is also a matter of concern that how much value is given to opinions expressed during the public hearing. Most projects are located in the resource rich tribal and rural areas. Due to the inherent social conditions in such areas, such as lack of literacy and the simple nature of Tribals, people are easily convinced and lured by the prospect of money and jobs. The notification does not prescribe clear and well defined guidelines for conducting the public hearing. The bearing of the expenses involved in conducting the public hearing are not dealt with by the notification.

This is another problem with no clear answers. The documents which the public are entitled to are seldom available on time. The notification prescribes a number of places where one can access these documents , but does not stipulated who is responsible for ensuring that the documents are made available at these locations. The mentioned websites are not updated.The result is that one seldom finds the documents available at the designed locations. In many cases minutes of public hearing or recommendations of the public hearing panels do not reflect the actual proceedings and objections raised. Further the recommendations of the public hearing panel are only advisory and it is not mandatory for the impact assessment agency to even consider these while granting environmental clearance to projects.

The Indian Judiciary has performed a stellar role in protecting the rights of people to participate in environment decision making by the tool of judicial review and relaxing the rule of locus standi. But the real challenge lies before the legislature and the executive in the developing country like India. The state has taken up the role of a welfare state. But somewhere the thrust for the economic development has overshadowed the welfare functions of the state. Major projects are given permission and clearance on the justification that the economic development is the backbone of development of nation. In this race for economic progress, the goals of welfare and socialistic state are ignored. To make the balanced progress with keeping in mind the developmental goals and socialistic goals, a wise and balanced approach is required from the organs of the state. What is lacking is the vital resources to invest in building the capacity of local communities to influence and inform national policy making. The positive efforts to increase the literacy rate will definitely help the affected group to fight for their right.

The provisions for public hearing should not be taken as a mere procedure but the strict monitoring of public hearing would bring positive result. The procedure of public hearing should not be confined to those projects which are specified in the schedule to the main EIA notification but it should be made mandatory for all those which may have possibility of causing any effects on the environment. Wherever there is any threat to the people's right to environment, the government should assume the role of parens patriae to protect it. With the advent of National Green Tribunal the confidence is built up that people's right to participation would be taken care of. But the real need is to educate the people about their procedural rights of effective participation in environmental decision making process. 


\section{REFERENCES}

[1] R. Picolotti and D.Taillant (Ed.), Linking Human Rights and the Environment, (Tucson, AR: University of Arizona Press,2003) 50.

[2] D.Hunter, Using the World Bank Inspection Panel to defend the interests of Project-affected people, Chicago Journal of International Law 4, 2003, 201-11.

[3] Shyam Diwan and Armin Rosencranz, Environmental Law and Policy in India - Cases, Materials and Statutes (2nd ed., 2001)

[4] C. Shashtri, Environmental Law in India, Eastern Book Company, Lucknow. (2015)

[5] P. Leelakrishnan, Environmental Law in India (2nd ed., 2005)

[6] Gurdip Singh, Environmental Law in India (2005)

[7] Kailash Thakur, Environmental Protection Law and Policy in India (1997), Deep \& Deep publications, New Delhi. 